\title{
Depictions of Martin Luther King, Jr. in Public Art from 1967 to the Present
}

\author{
Alison Flanagan ${ }^{1, *}$, Kevin Concannon ${ }^{2}$ \\ ${ }^{1}$ Hargrave Military Academy, USA \\ ${ }^{2}$ School of Visual Arts at Virginia Tech, USA
}

Copyright $\bigcirc 2017$ by authors, all rights reserved. Authors agree that this article remains permanently open access under the terms of the Creative Commons Attribution License 4.0 International License

\begin{abstract}
This research tracked the representations of Martin Luther King, Jr. in public art from 1967 until the present. The author's theory before beginning research was that depictions of Martin Luther King, Jr. have changed since his death. The author propounded that public opinion of King was negative during his lifetime but transformed into a positive viewpoint after his assassination. The author formulated that public art of King would change from before and after his death and that this artwork would reflect the artists' or patrons' agendas more so than any objective portrayal of King. The goal of the research was to evaluate public art examples, analyze them for their motivation, and either prove or disprove the original theory.
\end{abstract}

Keywords Martin Luther King, Jr., MLK, Public Art, Murals, Wall of Respect, Sculpture

\section{Introduction}

The research for this article took a full year and was an expansive overview of public art broken down into decade studies. There has been little formal writing on this topic, though what has been written is included in the Literature Review. An invaluable resource was Camilo J. Vergara's photography study of street art depicting Martin Luther King, Jr. Due to the transient nature of public art Vergara's photographs are often all that remains of the art they documented. This series was used as the basis for the initial research though the lack of outside sources and additional information on many of Vergara's photographs meant few were included in the completed study.

\section{Materials and Methods}

Research was conducted from August 2015 until May 2016. Public art, both government and privately funded, that depicted Martin Luther King, Jr. (either representationally or thematically) and were created between 1970 and 2016 were considered for this study. Five works were picked to study in depth for each decade. These works were chosen because they had the most verification from multiple sources and represented the broadest possible range of opinions and artistic techniques. Due to length requirements, only one work per decade (one that follows the most common artistic representation from that decade) is discussed in this essay. Works of art were chosen from published academic literature or online databases. Unfortunately, due to the transient nature of many public art works (which are destroyed when buildings are taken down, painted over, or removed by other artists or property owners), works that could have their time frame, artist, and location verified (even if they are now destroyed) received the priority for being included in this study. In addition, one work is included that does not fit this above criteria: the Wall of Respect made in 1967. This piece is included because it is a vital indicator of public opinion of King while he was still alive and serves as the foundation and starting point for this research.

\section{Results}

The author's theory proved correct. Before King's death, African American communities generally thought that his methods of activism were ineffective, and the government did not hail him as a hero. After Dr. King's death, representations of him in public art differ dramatically depending upon the artist or patron, and reflect a version of King that serves the politics of those creating the mural or monument. Most often, this means a positive portrayal of King's work and activism as private citizens hail him as a martyr and government commissions promote his non-violent method of activism.

\section{Discussion}

The study began by looking at the Wall of Respect (1967) 
mural. This may seem like an unusual piece to start with since it was the only piece studied that did not actually include Martin Luther King, Jr. The critical element to this piece is that it was created to feature African American heroes and was made while King was still alive. These heroes were selected first by the African American artists who proposed the mural and then confirmed or rejected by the residents of the Southside Chicago neighborhood in which it was made. As Michael Harris [1] explains, when the artists were considering which heroes to include on their wall (Figure 1) King was discussed but he was ultimately rejected because his approach to activism was not considered radical enough. The Art Institute of Chicago [2] explains this in depth. Stokely Carmichael (creator of the Black Panthers slogan and a far more violent activist) was chosen instead.

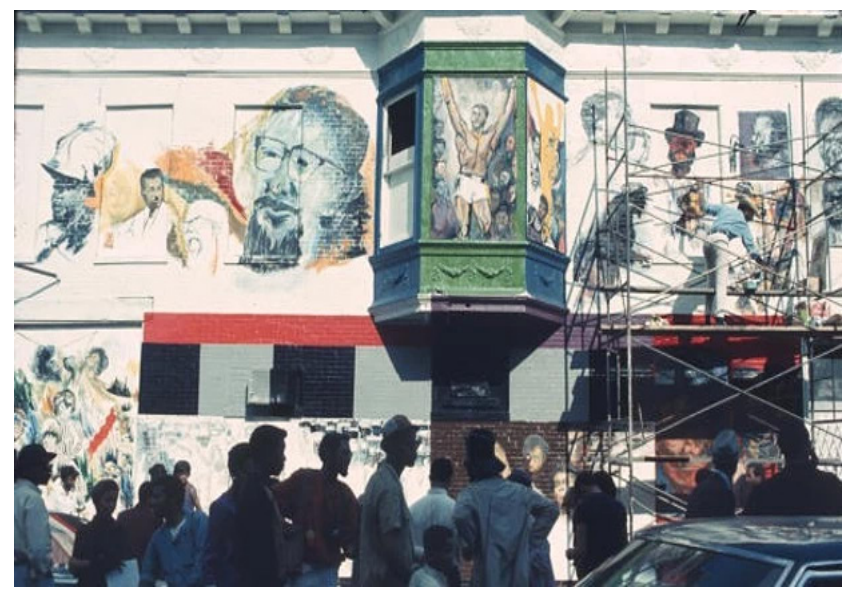

Source: The Guardian (Campkin)

Figure 1. Photograph of the Wall of Respect, 1987.

This well-documented work of art is incredibly valuable because it gives us a clear view of how Martin Luther King, Jr. was seen, by African American artists and communities, during his lifetime. His type of activism was not considered radical enough to produce change and therefore, he was not seen as a positive role model for his peers.

However, if we look at present times and consider the huge number of memorials to Martin Luther King, Jr. it is clear that there is currently a positive public opinion of this leader. Therefore, the viewpoint changed after his death; but when and how exactly? This study traced examples, with an average of 5, from each decade. The goal was to work with a variety of locations, artists, and stakeholders in this study. For the sake of brevity, this paper will only look at one representative work from each decade. Effort was taken to select pieces that show not just a variety in media used but also a broad range of public art stakeholders in the works..

Martin Luther King, Jr. was assassinated in 1968, thus the first decade studied in depth was the 1970s. The 1970s are considered the Second Renaissance for African American mural art. Everywhere in major cities, public art could be viewed on the outsides of buildings. Murals showing Martin Luther King, Jr. began appearing (albeit slowly) in cities, and now he was represented in a positive light. A distinctive example of this is Charles Freeman's mural Sojourner Truth. The Mural Conservancy of Los Angeles [3] explains that this mural was created on the side of Locke Continuations High School on 325 East 111th St. in Los Angeles, CA. All indications point to this being a community mural for which Freeman talked with those who lived (and went to school) in this area in order to have permission to create this piece on their wall.

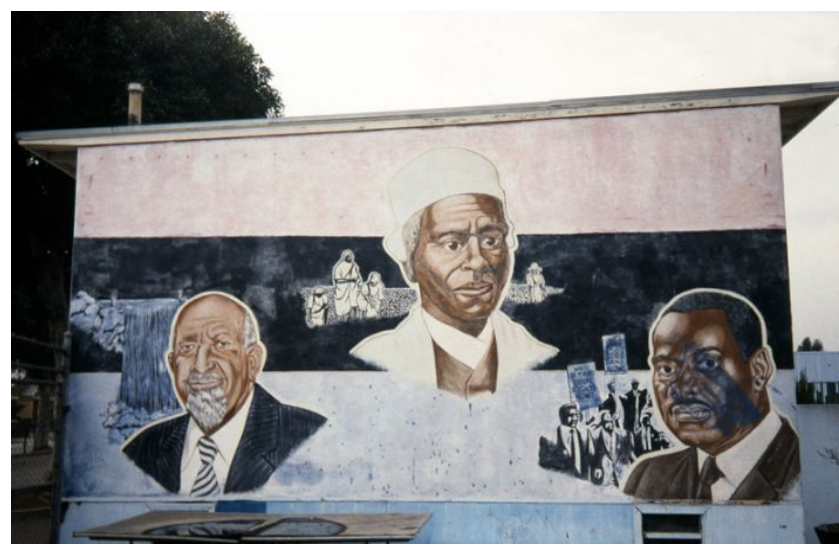

Source: Conservator of Los Angeles

Figure 2. Photograph of Sojourner Truth by Charles Freeman, year unavailable

In Figure 2, you can see Martin Luther King, Jr. represented alongside Sojourner Truth and W.E.B. Dubois. These other figures are clearly positive role models and important African American figures from history. By depicting King next to them, Freeman is creating a positive correlation and showing him as a significant contributor to society and African American culture. This mural was created just years after King's untimely death but shows the shift from rejecting King as a role model in the African American community to portraying him as a hero.

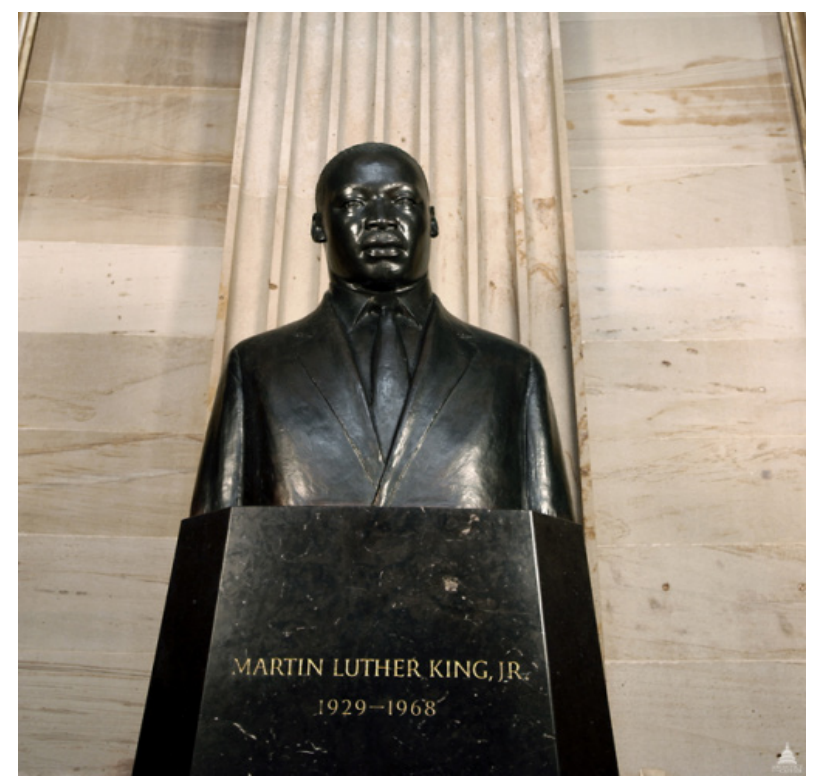

Source: Architect of the Capital

Figure 3. Photograph of Martin Luther King, Jr. Bust in Capitol Rotunda, 2011 
If we look beyond 1970 into the 1980s, we can analyze a federally funded public work of art. In 1986, almost two decades after King's assassination, a bust of Martin Luther King, Jr. was erected in the Capitol Rotunda in Washington, D.C (Figure III.) As the Architect of the Capital [4] explains, this bust was the first sculpture of an African American in the halls of Congress. The groundwork for its creation began in 1982 when Congress passed a resolution calling for a bust of Martin Luther King, Jr. to be commissioned to commemorate all of his contributions to civil rights. The planning for this statue has been generally applauded. Dr. King's wife even served on the planning committee and helped select the sculptor.

The design of the sculpture is unique compared to many others in this space in that it is not a full body sculpture but rather a bust. This creates an interesting, surreal element to the subject. Unfortunately, this bust does not seem to fully realize the potential of what it could have been. Since it was added as a special commission, it had the potential to include words on the stand explaining King's triumphs, stances, etc. Instead, the work exists but simply notes the subject's name. It feels more like a simple appeasement of a desire for diversity in the Rotunda, rather than a celebration of everything for which King fought. Even though it falls short of its potential, the very fact that Congress passed a resolution for this sculpture and installed it in a government building shows that both the government, and public opinion, changed since King's death to favor the activist. In the federal government's case, it took nearly two decades for them to embrace and promote King's life and work.

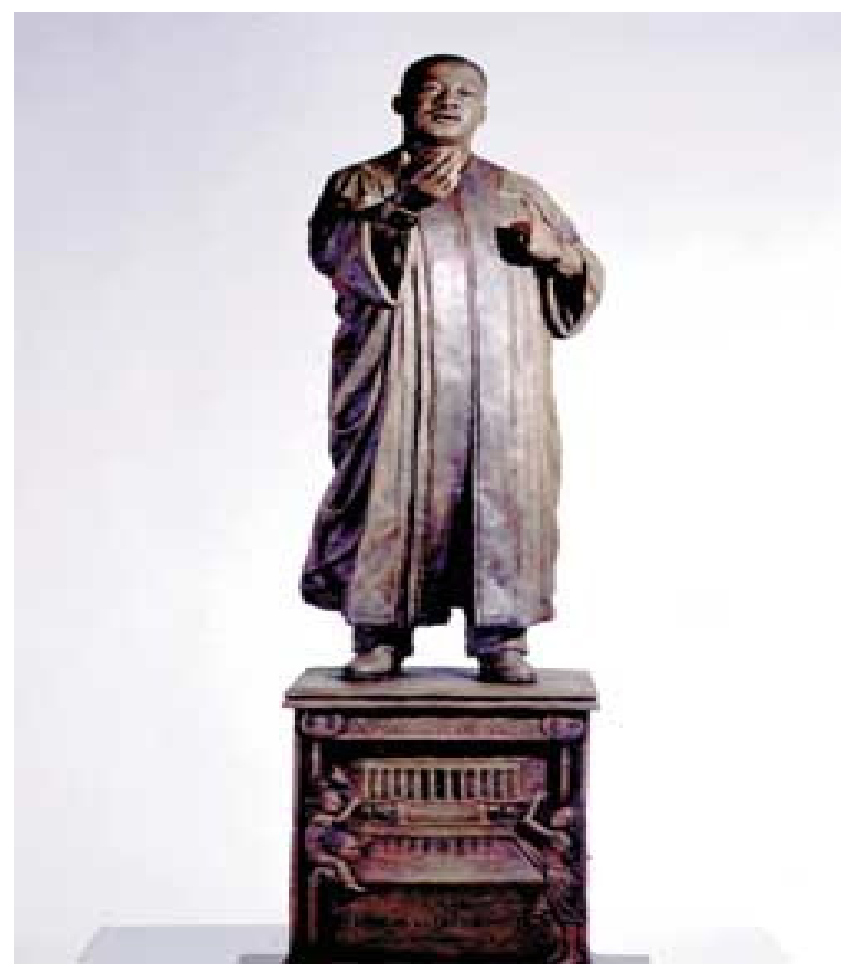

Source: "The Martin Luther King Jr. Sculpture Project"

Figure 4. Photograph of Dr. Martin Luther King statue on University of Texas campus, 1999.
In the 1990s, public art was thriving. There were now many great public art depictions of Martin Luther King, Jr., but one coming from a very unexpected location was a student-commissioned sculpture on the campus of the University of Texas at Austin (Figure 4). Jim Nicar [5] explains the background of this public art in his article, "How the MLK Statue Came to the East Mall." The idea for this piece started in 1987 when a group of students wanted a statue on campus that addressed the issue of segregation and racism. The idea was approved by the president of the university but students were responsible for raising all of the funds. Through a lengthy process of fundraising and choosing a suitable artist for the project, the sculpture was eventually unveiled on the East Lawn in 1999. This work was the second representation of King on a college campus (the first being at his alma mater Morehouse). It is worth noting that Morehouse has regularly celebrated King, holding yearly talks and discussions on him and expanding their works of him and about him into the "King Collection." It makes sense that Morehouse would celebrate and promote their most famous alumni. It is a bit more surprising that the University of Texas at Austin would feel the same connection to him. The students who wanted to create this sculpture saw King as a successful activist who addressed and confronted segregation and racism. They wanted to honor him as well as promote a continued battle against segregation and racism through this sculpture. This piece is pertinent because it shows shows public opinion, and a decade of college student's passion for this project, literally hailing King as a hero.

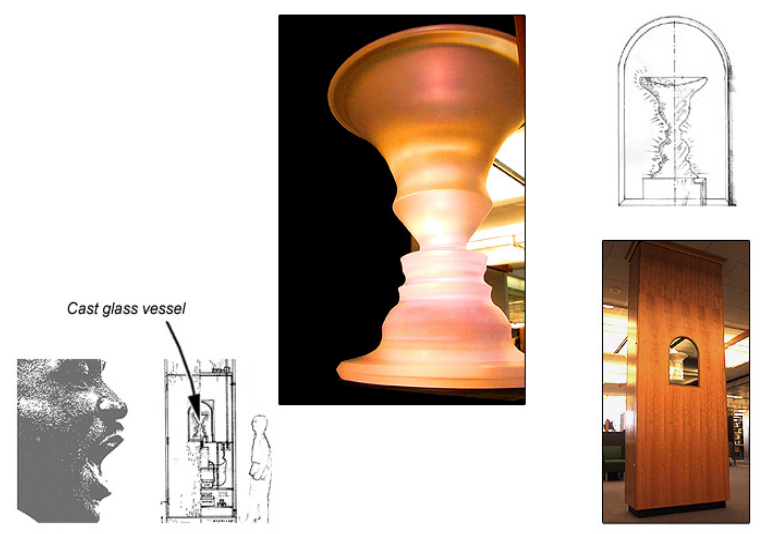

Source: "Dr. Martin Luther King Jr. Library"

Figure 5. Design drawings and photos explaining the work Vessel by Mel Chin, 2003

In the 2000s, an example of public art showing Martin Luther King, Jr. can be found in the Martin Luther King, Jr. Library in San Jose, California. In accordance with laws that require $1 \%$ of building costs to go towards artwork for those buildings, an artist was asked to create artwork throughout the building that would describe works that the building held. Mel Chin, an internationally recognized artist, was tasked 
with designing artwork and interactive visuals throughout the new Martin Luther King, Jr. library building. The website for the library [6] has a page for this specific piece (Figure 5) called "Vessel" which is a glowing vase, with King's silhouette on either side, and varying tones of white, tan, and brown on the piece itself. Chin said these tones were supposed to show the varied skin tones that make up San Jose's population and the color ratios actually correspond to the racial diversity ratios in the city. Mel Chin worked on this project from 1997-2006 producing a highly successful and visually interesting building interior. Not only do Mel Chin's complex and intricate pieces show King's impact on popular culture in this decade, but the very fact that a created library was named after King shows his impact and the positive opinion that culture now has about him.

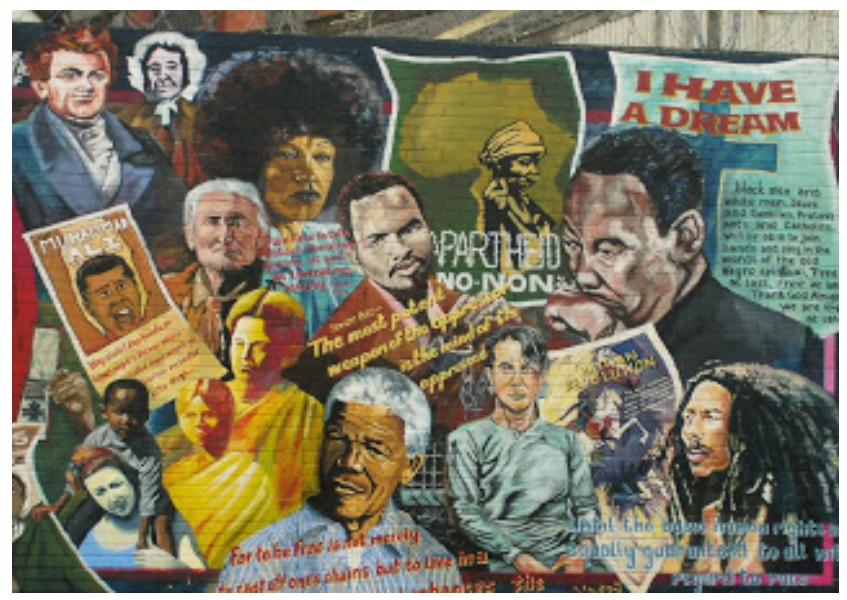

Source: Fought, Leigh.

Figure 6. Photograph of Frederick Douglass Civil Rights mural in Belfast, 2011

The last case example was documented in 2011 and can be found all the way in Northern Ireland. Of course, when we look outside the United States, there is a whole new set of cultural histories and ideologies to consider. Details such as who created this piece (Figure 6) are unknown, though the majority of murals in this area are artist-controlled by those who wish to express their personal beliefs and ideas or respond to some already created murals. "Beyond_the Troubles: Murals of Belfast, Northern Ireland" [7] provides background on the culture and history of this trend. For this piece, the artist(s) used people such as Barack Obama and Martin Luther King, Jr. to draw connections to their own fight and struggle for civil rights. Ireland's protests and marches have actually been modeled after African Americans' nonviolent protests create a sense of kinship. Ireland's conflicts lie in tensions between Catholics and Protestants, with Catholic artists, especially in this area, often creating murals about human rights issues. In this piece, Catholic Irish see their own struggles as a parallel to Martin Luther King, Jr.'s fight for equality. Now we see the full reach of Martin Luther King Jr's impact. Not only did he progress from a negatively viewed activist during his lifetime to a positive role model for African Americans, he became a symbol throughout America of activism and positive change. With this example, we see his reach beyond America and across the globe as others use both his methods and his portraiture to inspire and encourage them in their own struggles.

\section{Conclusions}

The theory for this study proved correct. Martin Luther King, Jr. went from being a figure excluded from murals and not widely considered a success, even among African Americans, to a man celebrated and promoted for his civil rights work not just in the U.S. but worldwide. The variety of stakeholders shown in these examples helps demonstrate this point. Some of the works are artist-generated and want to use King's struggle and compare it to other well-known and respected civil rights leaders. Some are community-funded by people who see King as being vital to a change in American culture and want to honor him. Last, others are commissioned by the government wanting to mark a vital moment in American history. By tracking the dates, meaning, and stakeholders in public art, we can see that this shift in public opinion of Dr. Martin Luther King Jr. definitively happened, growing slowly in popular culture, after his death in 1968.

\section{REFERENCES}

[1] Harris Michael, Prigoff, James, and Robin J. Dunitz. "Totems: The Communal Spirit of Black Murals." In Walls of Heritage, Walls of Pride: African American Murals. San Francisco: Pomegranate, 2000.

[2] Online Available: "The Wall of Respect." Available online at: www.artic.edu/ ljunki/mightyblackwall.doc

[3] Online Available: "Sojourner Truth." Conservator of Los Angeles. Available online at:

http://www.muralconservancy.org/murals/sojourner-truth

[4] Online Available: "Martin Luther King, Jr. Bust" Architect of the Capital. Available online at

http://www.aoc.gov/capitol-hill/busts/martin- luther-king-jrbust

[5] Online Available: Nicar, Jim. "How the MLK Statue Came to the East Mall." The Alcalde. Available online at: http://alcalde.texasexes.org/2012/02/mlk-on-the-east- mall/

[6] Online Available: "Dr. Martin Luther King Jr. Library." Vessel. Available online at:

https://www.sjlibrary.org/content/vessel

[7] Online Available: Beyond The Troubles: Murals of Belfast, Northern Ireland." Web Urbanist. Available online at: http://weburbanist.com/2007/08/03/beyond-the-troubles-mura ls-of-belfast-northern-ireland/

[8] The following sources were used for research and although not all are directly quoted or referenced in the text (only those listed in References) all of them influenced the findings in the above, abbreviated, version of the study. 
[9] “(1946) W.E. B. DuBois, "Behold the Land"; The Black Past: Remembered and Reclaimed. 2013. Accessed November 30, 2015.

[10] "2013 Martin Luther King Jr. Celebrations at Morehouse College in Atlanta." Morehouse College Alumni Association. January 9, 2013. Accessed December 1, 2015 http://www.morehousecollegealumni.com/2013/01/09/2013martin-luther-king-jr-celebrations-at-morehouse-college-in-at lanta/.

[11] "A Teaching of History and Culture in South Los Angeles." It's About Time - Black Panther Party Legacy \& Alumni 45th Year Reunion. Accessed December 1, 2015. http://www.itsabouttimebpp.com/.

[12] Appiah, Anthony. Africana: The Encyclopedia of the African and African American Experience. New York: Basic Civitas Books, 1999.

[13] "Beyond The Troubles: Murals of Belfast, Northern Ireland.\&quot; Web Urbanist. August 3, 2007. Accessed December 2, 2015.

[14] "Bio." Mel Chin. Accessed December 1, 2015. http://melchin.org/oeuvre/mel-chin.

[15] "Building the Memorial." The National Park Service. Accessed May 1, 2016.

[16] Campkin, Ben, Mariana Mogilevich, and Rebecca Ross."Chicago's Wall of Respect: How a Mural Elicited a Sense of Collective Ownership." The Guardian. December 8, 2014. Accessed November 30, 2015.

[17] "Charles 'Boko' Freeman: The Eternal Panther." It's About Time - Black Panther Party Legacy \&amp; Alumni 45th Year Reunion. Accessed December 1, 2015.

http://www.itsabouttimebpp.com/Our_Stories/Chapter5/pdf/B oko The Eternal Panther.pdf.

[18] Collins, Lizzetta, and Shifra M. Goldman. "African-American Modernists and the Mexican Muralist School." In In the Spirit of Resistance: African-American Modernists and the Mexican Muralist School - En El Espiritu De La Resistancia: Los Modernistas Africanoamericanos Y La Escuela Muralista Mexicana, 27-68. New York, New York: American Federation of Arts, 1996.

[19] Coonerty, Ryan, and Carol M. Highsmith. "Martin Luther King International Chapel." In Etched in Stone: Enduring Words from Our Nation's Monuments, 40. Washington, D.C.: National Geographic, 2007.

[20] Dellinger, Hampton. "Righting Two Martin Luther King Memorial Wrongs." The Atlantic. January 21, 2013. Accessed May 1, 2016.

[21] "Documenting the American South." Commemorative Landscapes of North Carolina. Accessed December 1, 2015.

[22] "Dr. Martin Luther King Jr. Library."; Vessel. Accessed December 1, 2015. https://www.sjlibrary.org/content/vessel.

[23] Eversley, Melanie. "MLK Jr. memorial confronts controversy." USA Today. July 5, 2011. Accessed May 1, 2016.

[24] Fallon, Michael. Creating the Future: Art \& Los Angeles in the 1970s. Counterpoint Press, 2014.
[25] Fought, Leigh. "Douglass in Belfast." Frederick Douglass's Women: In Progress. November 8, 2011. Accessed December 2, 2015. http://leighfought.blogspot.com/2011/11/douglass-inbelfast.html.

[26] Friedman, Uri. "The Many Problems People Have With the MLK Memorial." The Wire. August 26, 2011. Accessed May $1,2016$.

[27] Fuetsch, Michele. "Murals With a Message for Society: Painter Captures the Spirit Behind Struggle in Compton." Los Angeles Times. August 31, 1989. Accessed December 1, 2015.

[28] Gambino, Megan. "Building the Martin Luther King, Jr. Memorial." Smithsonian. August 18, 2011. Accessed May 1, 2016.

[29] Gordy, Cynthia. "The MLK's Memorial Complicated History." The Root. August 22, 2011. Accessed May 1, 2016.

[30] Harris Michael, Prigoff, James, and Robin J. Dunitz. "Totems: The Communal Spirit of Black Murals.” In Walls of Heritage, Walls of Pride: African American Murals. San Francisco: Pomegranate, 2000.

[31] Huebner, Jeff. "The Man Behind the Wall." N.p., 28 Aug. 1997. Web. 1 Dec. 2015.

[32] Kwon, Miwon. 2002. "Sitings of Public Art: Integration versus Intervention" One Place After Another: Site Specificity and Locational Identity (2002): 1-39. Accessed November 1, 2015. http://web.mit.edu/allanmc/www/kwon1.pdf.

[33] "Library of Congress Records" Library of Congress. Accessed October 31, 2015.

http://www.loc.gov/pictures/item/2015647520/.

[34] Locke, Alain. The Negro in Art; a Pictorial Record of the Negro Artist and of the Negro Theme in Art. New York, New York: Hacker Art Books, 1971.

[35] Longwell, Lance. "Derry Murals - The Troubles of Northern Ireland." Travel Addicts. November 10, 2013. Accessed December 2, 2015.

[36] Marter, Joan M. The Grove Encyclopedia of American Art. Oxford: Oxford University Press, 2011.

[37] "Martin Luther King, Jr. Bust" Architect of the Capital. September 24, 2014. Accessed November 1, 2015. http://www.aoc.gov/capitol-hill/busts/martin-luther-kingjr-bust.

[38] Martin Luther King Jr. by Mural” January 12, 2011. Smithsonian. Accessed October 31, 2015. http://www.smithsonianmag.com/arts-culture/martinluther-king- jr-by-mural-12207/?no- ist.

[39] Miller, Don. "Installation of Martin Luther King Jr. Mural inside Martin Luther King Jr. Memorial Library" DC Public Library Archives. Accessed December 2, 2015.

[40] "Morehouse College Campus Map." Accessed December 1, 2015.

https://www.morehouse.edu/commencement/pdf/Campus-Ma p.pdf.

[41] Otfinoski, Steven. "Donaldson, Jeff."; In African Americans in the Visual Arts, 66-67. New York, New York: Facts on File, 2003. 
[42] Otten, Liam. "American Art of the 1980s" Washington University in St. Louis. December 8, 2003. Accessed November 1, 2015. http://news.wustl.edu/news/Pages/565.aspx.

[43] Patton, Sharon. 1998. "Timeline.” In African-American Art, 308. Oxford University Press, 1998

[44] Pearson, Lynn F. Public Art since 1950. Princes Risborough: Shire, 2006. 17-20.

[45] Powell, Richard. "African American Art.”; Artlex. April 1, 2005. Accessed November 30, 2015. http://www.artlex.com/ArtLex/a/african_american_7.html.

[46] "Public Art San Jose Downtown." Accessed December 1, 2015.

https://www.sanjoseca.gov/DocumentCenter/View/26100.

[47] "Recolecciones." Mel Chin. Accessed December 1, 2015. http://melchin.org/oeuvre/recolecciones.

[48] "Recolecciones.” MLK Library-. Accessed December 1, 2015. http://oleglyutov.com/mlk_library/collections/recolecciones/.

[49] "Sojourner Truth." Mural Conservator of Los Angeles. Accessed November 30, 2015.

http://www.muralconservancy.org/murals/sojourner-truth.

[50] Soynoise, Youtuber. "Charles 'Boko' Freeman / Black Panther Party" YouTube. October 16, 2010. Accessed December 1, 2015. https://www.youtube.com/watch?v=QmhEiTiu6kM.
[51] "The King Collection." Morehouse College. Accessed December 1, 2015.

[52] "The Martin Luther King, Jr. Memorial." Washington DC. Accessed May 1, 2016.

[53] "The Martin Luther King Jr. Sculpture Project." The Martin Luther King Jr. Sculpture Project. Accessed December 1, 2015.

[54] "The Murals | Magic in Medicine." Harlem Hospital WPA Murals. Accessed November 19, 2015. http://iraas.columbia.edu/wpa/magicmeds.html.

[55] "The Wall of Respect." www.artic.edu/ ljunki/mightyblackwall.doc. Accessed November 30, 2015.

[56] Upton, Dell. What Can and Can't Be Said: Race, Uplift, and Monument Building in the Contemporary South. Yale University Press, 2015.

[57] Visconti, Luca M. Sherry Jr., John F. Borghini, Stefania. Anderson, Laurel. "Street Art, Sweet Art? Reclaiming the 'Public' in Public Place." Journal of Consumer Research. April 7, 2010. Accessed May 1, 2016.

[58] "Wall of Respect." Mary \& Leigh Block Museum of Art. Accessed May 1, 2016.

[59] Widener, Daniel. Black Arts West: Culture and Struggle in Postwar Los Angeles. Durham, NC: Duke University Press, 2010. 169

[60] Williams, Robert. W.E.B. Du Bois. October 1, 2015. Accessed November 30, 2015. http://www.webdubois.org/index.html. 